\title{
IRON ABSORPTION DISTURBANCES IN PATIENTS WITH ENTEROPATHY: INTERIM ANALYSIS OF A SINGLE CENTRE STUDY
}

\author{
Oḷesja Basina ${ }^{1,2}$, Jeḷena Derova ${ }^{2,3}$, Aleksejs Derovs ${ }^{1,2,3, \#}$, and Sandra Lejniece ${ }^{2,3}$ \\ ${ }^{1}$ Rīga East University Hospital, 2 Hipokrāta Str., Rīga, LV-1038, LATVIA \\ ${ }^{2}$ Rīga Stradiṇš University, 16 Dzirciema Str., Rīga, LV-1007, LATVIA \\ ${ }^{3}$ Latvian Maritime Medicine Centre, Rīga, LATVIA \\ Corresponding author, aleksejs.derovs@gastroenterologs.lv
}

Contributed by Sandra Lejniece

\begin{abstract}
There are about 2 billion people in the world who suffer from anaemia, mostly iron deficiency anaemia (IDA), by WHO data. Iron deficiency without anaemia is three times more common than IDA. In such patients, the condition of the small intestine should be evaluated, and malabsorption excluded. The aim of the study was to evaluate potential correlation between different types of enteropathy and iron absorption disturbances. The study was performed at the Latvian Maritime Medical Center "Gastroklinika" between the years 2014 and 2018. Iron absorption tests with $50 \mathrm{mg}$ of oral iron gluconate were performed for each patient. Patients had filled in a FACIT questionnaire and had underwent video capsule endoscopy (VCE). A total of 48 patients were enrolled for analysis - 41 (85.4\%) female and 7 (14.6\%) male. Enteropathy was diagnosed in 35 cases: erosive - 17, erythematous -12 and congestive - 6 . By the time of VCE, 24 patients were suffering from anaemia. A total of $33(68.7 \%)$ patients had problems with iron absorption, of whom 8 had no signs of enteropathy and 25 were diagnosed with enteropathy during VCE. IDA did not show a statistically significant correlation with enteropathy. However, the obtained results suggest that this should be studied further in association with small intestine malabsorption, to determine the precise role of enteropathy in IDA patients.
\end{abstract}

Key words: anaemia, oral iron absorption test, video capsule endoscopy, enteropathy.

\section{INTRODUCTION}

WHO data show that there are about 2 billion people in the world (about $30 \%$ of world population) who suffer from anaemia, mostly iron deficiency anaemia. Despite its mild clinical manifestation, such as profound fatigue, iron deficiency anaemia (IDA) is dangerous and its complications can even lead to premature death. In developed countries, IDA is predominantly diagnosed in patients because of other diseases, such as gastrointestinal, oncological, obstetric and gynaecological complications, or as a consequence of major blood loss, due to extensive surgical manipulation. According to the literature, the most common cause of IDA in women of childbearing age is menstrual disorder (such as frequent and severe menstruation), while at menopause age men and women usually suffer from IDA because of gastro- intestinal bleeding. Uncommon IDA causes include malabsorption syndrome of various genesis (celiac disease, Crohn's disease, etc.), different oncological and renal diseases, etc. (Cook et al.,1986; Zuckerman et al., 1992; Rockey et al., 1993; Kepczyk et al.,1995; Hardwick et al., 1997; Guralnik et al., 2004; James et al., 2005; De Benoist et al., 2008; Goddard et al., 2011).

The precursor of IDA is latent iron deficiency. At this stage, there is a shortage of iron reserves and depot stocks are running out. Correspondingly, a decrease in ferritin levels is observed while serum iron levels are normal and/or elevated. No clinical manifestations are observed at this stage. This condition is usually detected by accident just performing screening of ferritin levels. Iron deficiency without anaemia is three times more common than IDA. In such pa- 
tients, the condition of the small intestine should be evaluated, and malabsorption excluded. Treatment should be started empirically with oral iron supplement and potential anaemia rates should be reassessed usually after three months. It should be noted that only $15-20 \%$ of iron is absorbed from the total daily iron intake. In addition, the socalled "haem" (Fe2+) iron contained in meat and meat products is best absorbed. In this case, iron is divalent and enters enterocytes relatively quickly. On the other hand, trivalent, "non-haem" (Fe3+) iron in fruits and vegetables requires a complete cascade of transformation to enter the bloodstream. The duodenum and jejunum proximal part play key roles to ensure adequate iron absorption (Kumar et al., 2010, pp. 659-661; Hall, 2011, at p. 419; Hoffman et $a l ., 2013)$. That is why it is crucial to evaluate these parts in detail for patients with latent iron deficiency, in cases when the aetiologic factor of iron deficiency has not been established.

Interest in endoscopic examination of small intestine has existed for years, but in clinical practice it was not possible for many years due to the anatomical location of the organ. Some of the methods developed, such as laparoscopy endoscopy, are still in the surgeons' arsenal in these cases, but their use is limited by strict indications. Thanks to a relatively new endoscopic examination method, namely video capsule endoscopy (VCE), adopted in clinical practice at the beginning of the century, it is now possible to evaluate the small intestine mucosa and identify the type of lesion (Pokrotnieks et al., 2000; Ginsberg et al., 2002; Lewis et al., 2005).

VCE is the most advanced and accurate diagnostic method used in the small intestine, which is difficult to examine, and provides an overall view of the entire digestive tract. Since small intestine reaches 5-7 meters, one of the possible methods of examination is either device-assisted enteroscopy or capsule endoscopy. The benefits of the method are often discussed in comparison to the competing (and often complementary) balloon enteroscopy. There are even some reports from endoscopy centres that it is a standard of good practice to start with capsule endoscopy and then if needed (biopsies, therapeutic interventions), continue with standard endoscopy. Both procedures are relatively safe, with high diagnostic and therapeutic yields that allow evaluation of the small bowel. However, the balloon enteroscopy procedure is laborious, labour-intensive and time-consuming and does not guarantee a complete review of the small intestine, even when the endoscope is administered to the same patient, both orally and anally. Furthermore, VCE is an optional diagnostic method for patients with iron deficiency anaemia of uncertain aetiology, gastrointestinal bleeding of uncertain aetiology, Crohn's disease and suspected small bowel tumour (Pokrotnieks et al., 2000; Ginsberg et al., 2002; Napierkowski et al., 2005; Rey et al., 2006; Rondonotti et al., 2007; Sidhu et al., 2008; Ladas et al., 2010).

Enteropathy is a generic name for various diseases of the small intestine. The condition is characterised by changes in the mucous membranes of the small intestine due to inflammation, which often leads to changes of the intestinal villus, erosions of the mucous membranes and ulcers. The aetiology of enteropathy can sometimes be identified, for example - gluten enteropathy and medication enteropathy non-steroidal anti-inflammatory drugs (NSAID). Nosologically diagnostics of enteropathy usually is one of the biggest challenges in modern gastroenterology (Allison et al., 1992; Bjarnason et al., 1993; Goldstein et al., 2005; Graham et al., 2005; Maiden et al., 2005; Aabakken et al., 2009; Feldman et al., 2010, at pp. 1797-1819). The clinical picture of enteropathy may be described by a combination of chronic diarrhoea and malabsorption syndrome. Pain syndrome is usually uncommon, but may become the leading symptom in case of ileus. Blood tests often reveal microcity anaemia or malabsorption due to B12 deficiency anaemia. Leucocytosis, accelerated erythrocyte sedimentation rate, elevated C-reactive protein levels, faecal calprotectin are indicative of an inflammatory process (Feldman et al., 2010, at pp. 1797-1819).

The analysis of capsule endoscopy data uses endoscopic classification of enteropathies: erythematous, erosive, haemorrhagic, congestive, NSAID-associated, proteinlosing enteropathy, and gluten-sensitive (in celiac disease) (Aabakken et al., 2009; Farlex et al., 2014). The last three (NSAID-associated, protein-losing enteropathy, and glutensensitive) enteropathies are widely discussed in the literature and have a direct correlation with IDA. However, clinical relevance and possible association of other types of enteropathy, such as erythematous, erosive, congestive and haemorrhagic with latent iron deficiency or iron deficiency anaemia is unclear. The aim of this study was to evaluate potential correlation between different types of enteropathy and iron absorption disturbances. A secondary endpoint was to evaluate correlation between FACIT-fatigue score and presence of anaemia.

\section{MATERIALS AND METHODS}

Patient selection. Age restriction was applied to paediatric patients. Only those patients who satisfied the inclusion criteria and were able to follow the instructions were enrolled in the study.

The inclusion criteria were:

- both genders and adult patients;

- had already performed upper and lower endoscopy;

- no contraindications for VCE;

- data available on full blood count, iron and ferritin levels at least four weeks before VCE.

The exclusion criteria were

- patients, who already had a diagnosis of gluten-sensitive enteropathy or positive celiac disease serology tests (transglutaminase or endomysial antibodies); 
- no latent iron deficiency / iron deficiency anaemia;

- patient regularly used non-steroidal anti-inflammatory drugs at least two months before VCE;

- patients with chronic renal disease and protein-losing enteropathy that were confirmed by capsule endoscopy, were retrospectively excluded from the study.

The study was performed at the Latvian Maritime Medical Center "Gastroklinika" from November 2014 to November 2018. Written informed consent to undergo a VCE procedure and oral iron absorption test was obtained from each patient.

Iron deficiency anaemia. We used the WHO definition of anaemia: Iron deficiency anaemia is defined by the combination of a low haemoglobin $\mathrm{Hb}<12 \mathrm{~g} / \mathrm{dl} \quad(7.4 \mathrm{mmol} / \mathrm{l})$ in women, $13 \mathrm{~g} / \mathrm{dl}(<7.7 \mathrm{mmol} / \mathrm{l})$ in men, low serum iron $(<7.1 \mu \mathrm{g} / \mathrm{l})$, low serum ferritin (storage form of iron) $(<30 \mathrm{ng} / \mathrm{l})$, and low transferrin saturation $(<15 \%)$.

Video capsule endoscopy. For VCE we used one capsule endoscopy system: OMOM Capsule Endoscope. The Capsule Endoscopy system was equipped with the standard software application. Pictures were taken at the rate of 2 fps. All patients underwent standard bowel preparation prior to VCE. One interpreter with experience of more than 600 VCE evaluated each case. Internationally recognised definitions and criteria were used for interpretation (Aabakken et al., 2008).

Enteropathy. Enteropathy was defined as any disorder of the intestine. There was no publication found in the MEDLINE database, which could precisely define the types of enteropathy mentioned below. That is why we developed our own definitions for different types of enteropathy found by VCE. With the term of erythematous enteropathy, we defined a pathologic condition of the small bowel, which was characterised by redness of the mucosa and abnormal look of the villi. With the term of congestive enteropathy, we defined a pathologic condition of the small bowel, which was characterised by plethora of the mucosa (swelling villi) and was outlined against a spastic bowel background. With the term of erosive enteropathy, we defined a pathologic condition of the small bowel, which was characterised by visually diagnosed multiple various size erosions in each part of the small bowel (duodenum, jejunum, ileum). With the term of haemorrhagic enteropathy, we defined a pathologic condition of the small bowel, which was characterised by visually diagnosed multiple bleeding small bowel lesions. With the term of segmental enteropathy, we defined a pathologic condition of the small bowel, which was characterised by isolated damaged mucosal segments in the small bowel (Derovs et al., 2012, pp. 11-14.).

Oral iron absorption test (OIAT). Due to technical reasons, we could not perform VCE and OIAT in one day, so the procedures were split in time. The interval between the procedures was no longer than two months. OIAT is a good index for the evaluation of absorption defects and can be a screening clinical test of IDA. The low-dose OIAT test assumes that intestinal iron absorption is higher in irondeficient subjects than in those with normal or increased iron stores (Jensen et al., 1998; Hacibekiroglu et al., 2013).

The patients were given $50 \mathrm{mg}$ iron gluconate orally at 10:00 am on an empty stomach. S-iron was measured just before iron consumption by a venous sample for baseline T0, and after 1, 2 and $3 \mathrm{~h}$. Patients had no food or drink, except still water between T0 and T3h. All tests were conducted at the same qualified laboratory for research purposes. If iron levels increased three hours after the administering of the test, a level three times from baseline absorption in the intestine was considered normal.

FACIT questionnaire. Common symptoms of IDA include fatigue and exercise-associated dyspnoea, poor mental performance and cold intolerance. To capture the severity and impact of fatigue due to IDA we used the Functional Assessment of Chronic Illness Therapy — fatigue (FACIT-fatigue) scale. This is a 13-item instrument designed to assess fatigue/ tiredness and its impact on daily activities and functioning in a number of chronic diseases. The instrument includes items such as tiredness, weakness, listlessness, lack of energy, and the impact of these feelings on daily functioning (e.g., sleeping, and social activities). The FACIT-fatigue scale has sound measurement properties and is an appropriate and interpretable assessment of fatigue among IDA patients with various underlying conditions. Items are scored on a $0-4$ response scale with answers ranging from "Not at all" to "Very much so". To score the FACIT-fatigue, all items are summed to create a single fatigue score with a range from 0 to 52 . For all FACIT scales and symptom indices - the higher the score, the better the QOL (Yellen et al., 1997; Rosenzweig et al., 1999; Cella et al., 2002; Miller et al., 2013; Sarah et al., 2015).

Statistical analysis. Then patient's related data, VCE procedure related factors and iron absorption test related factors were entered into a database for further processing and analysis.

Continuous variables were expressed as mean \pm standard deviation, whereas the categorical ones were expressed as percentages. Comparison was made between patients with lesions at VCE and patients without lesions.

The Chi-square (Fisher's exact test) was used to measure association between anaemia and enteropathy. Statistical significance was considered at $p=0.05$ significance level. $p$ in the range of $0.05-0.10$ was considered that some association is present in the data (Greenland et al., 2016). The data was statistically processed with the IBM SPSS 25.0 software (IBM Corp., Armonk, NY, USA).

Ethical aspects. The research was carried out in accordance with the Helsinki Declaration and approved by the Riga East University Hospital Ethical Committee. 


\section{RESULTS}

Patient population. In the time period of the study we performed $70 \mathrm{VCE}$, of which we excluded 22 patients: seven due to exclusion criteria, eight patients could not complete the questionnaire and seven patients decided to quit the study because did not want to apply for OIAT. A total of 48 patients were enrolled for analysis - 41 (85.4\%) female and $7(14.6 \%)$ male. Patient age varied from 18 to 79 years (median age was $34.0( \pm 14)$ ).

VCE findings. Enteropathy was diagnosed in 35 cases $(72.9 \%)$ : erosive - $17(48.5 \%)$, erythematous - 12 $(34.3 \%)$ and congestive - $6(17.2 \%)$. There were no haemorrhagic enteropathies found in patients enrolled in the study. By the time of VCE half of the enrolled patients were suffering from anaemia (24 patients), 18 (75\%) patients had received a diagnosis of enteropathy and six $(25 \%)$ had no sign of enteropathy $(p=0.097)$. The results were not statistically significant, although we suggest that this might be a variable of interest.

Anaemia / latent iron deficiency. Latent iron deficiency (decreased ferritin level with normal haemoglobin levels in the normal range) was diagnosed was diagnosed in 17 patients $(35.4 \%)$.

OIAT showed that at T0, patients without enteropathy presented with iron levels from $2.6 \mathrm{mmol} / 1$ to $32.4 \mathrm{mmol} / \mathrm{l}$ and in patients with enteropathy the iron level was from 2.6 $\mathrm{mmol} / \mathrm{l}$ to $24.6 \mathrm{mmol} / \mathrm{l}$. After three hours, there was an increase of iron level from $9.65 \mathrm{mmol} / \mathrm{l}$ to $32.32 \mathrm{mmol} / \mathrm{l}$ in the patient group without enteropathy and $9.4 \mathrm{mmol} / \mathrm{l}$ to 24.6 $\mathrm{mmol} / \mathrm{l}$ in the group with enteropathy.

A total of $33(68.7 \%)$ patients had problems with iron absorption, of whom eight $(24.3 \%)$ had no sign of enteropathy and $25(75.7 \%)$ were diagnosed with a type of enteropathy during VCE.

Patients with anaemia had a FACIT-fatigue median score of 19.4 and patients without anaemia scored $26.15(p=0.087)$.

\section{DISCUSSION}

IDA is one of the most frequent problems of the modern world since almost one quarter of the population is anaemic. The highest prevalence of anaemia is in preschool-age children $(47.4 \%, 95 \%$ CI: 45.7-49.1), and the lowest is in men (12.7\%, 95\% CI: 8.6-16.9\%). The population group with the greatest number of individuals affected is non-pregnant women (De Benoist et al., 2008). Since we excluded children in our study and only included adults, we also observed this distribution as the study group included five times more women than men. Anaemia is more frequent in the 60- to 70-year old age group than in the 40-60 year-old group.

The prevention and treatment of iron deficiency is a major public health goal. Even patients that are asymptomatic should receive treatment because of high mortality risks. Challenges in treatment of iron deficiency usually include finding and addressing the underlying cause of IDA, as well as selecting a proper treatment option for a patient since all treatments have their flaws. The main approach is associated with restoration of iron levels by oral or intravenous infusions. Oral medication is easily administered and effective for most patients, as well as initial coast is low, but has gastrointestinal side effects, associated with prolonged treatment time and is not applicable in severe cases (Stanley et al., 2019).

Oral medication could be used for patients with IDA, but only in those cases that have no sign of enteropathy, since absorption in the small intestine requires healthy mucosa (Stanley et al., 2019). Our study showed that patients with enteropathy suffered from anaemia three times more than patients who did not have any changes in the small intestine. In this interim analysis we did not obtain a statistically significant correlation between the presence of enteropathy and anaemia, but a link between these two pathologies ( $p=$ 0.097 ) was suggested. Thus, this relationship requires further study. We speculate that a statistically significant correlation could be obtained by increasing the number of patients, since the total number of patients enrolled in our study was only 48 .

A very similar study on IDA using VCE suggested a need to promote morphologic agreements in discriminating and describing the different pictures, which may presumably account for the large VCE range (38-83\%) of the diagnostic yield in IDA (Rondonotti et al., 2007; Gerson et al., 2015; Antonella et al., 2019). In comparison to Contaldo et al., our analysis of VCE showed that the causes in the majority of cases of enteropathy were inflammatory and only secondarily were vascular (Antonella et al., 2019). This is interesting since we excluded patients that are actively using NSAIDs.

Absorption problems are also supported by OIAT, since patients with enteropathy had iron malabsorption and iron levels could not increase as much as expected in comparison with the second patient group. As iron absorption is generally between $10-20 \%$ of an oral dose, we should use quite high doses for replacement therapy. This high-dose treatment usually leads to common side effects and as consequence increases the duration of treatment and low patient compliance (Alleyne et al., 2008). And further, patients having more severe anaemia report a low quality of life, mostly because of chronic fatigue, as we demonstrated using the FACIT-fatigue scale.

Originally developed to assess cancer-related fatigue, the FACIT has utility as a measure of fatigue in other populations, such as stroke and HIV (Butt et al., 2012). The psychometric properties of the FACIT-fatigue scale were investigated using data from a phase 3 clinical trial assessing ferumoxytol in patients with a history of unsatisfactory oral iron therapy or in whom oral iron could be used. The statistical analysis assessed the acceptability, reliability, validity 
and responsiveness of the FACIT-fatigue scale. That study demonstrated that the FACIT-fatigue scale can produce sound estimates and that it can be used to make an appropriate and interpretable assessment of fatigue among IDA patients with various underlying conditions (Sarah et al., 2015). A higher FACIT-fatigue score is associated with better quality of life. In our study, statistical significance between anaemia and the FACIT-fatigue score was not obtained $(p=0.087)$. However, we need to examine the point estimate to determine the effect size most compatible with the data under our model. Once again, the $p$ level can be explained by the limited number of patients.

This leads us to the logical conclusion that, in cases of IDA when the upper and lower endoscopy does not reveal any pathology and the gynaecological tract was investigated (if applicable), it seems to be useful to use VCE for detection of enteropathy, because this provides a better choice of treatment approach and could gradually improve the patient's wellbeing.

Unfortunately, our study had several limitations. The number of patients enrolled in the study was small, which could be partially associated with our exclusion criteria, as celiac disease which is the most common enteropathy and the main indication for VCE is gastrointestinal bleeding. Secondly, we used visual evaluation of intestinal mucosa by VCE for diagnosis of enteropathy and in the absence of histological verification, which could be obtained using device-assisted enteropathy. This could partially limit diagnostic value. On the other hand, it should be noted that presently VCE is one of the leading tools for examination of small bowel. Furthermore, we are planning to continue this research, including more patients.

Finally, we speculate that possibly it would be useful to enrol another group of patients, such as healthy volunteers or patients with IDA and enteropathies who would receive primary treatment for enteropathy without iron substitution therapy. This would help in obtaining statistically significant results, because at the moment correlation between SB enteropathy and IDA shows only a tendency. This could minimise the limitations of the study.

\section{CONCLUSIONS}

IDA did not show a statistically significant correlation with enteropathy. However, the obtained results suggest this study of the association is important, as it potentially could be explained by small intestine malabsorption. Further research is needed to investigate the precise role of enteropathy in IDA patients.

\section{REFERENCES}

Aabakken, L., Rembacken, B., LeMoine, O., Kuznetsov, K., Jean-Francois, R., Rösch, T., Eisen, G., Cotton, P., Fujino, M. (2008). Minimal standard terminology for gastrointestinal endoscopy — MST 3.0. World Endoscopy Organization. http://www.worldendo.org/wp-content/uploads/2016/08/ 160803_MST30.pdf (accessed 28 February 2020).
Acaster, S. (2015). Qualitative and quantitative validation of the FACIT-fatigue scale in iron deficiency anemia. Health Qual Life Outcomes, 13, 60.

Alleyne, M., Horne, M. K., Miller, J. L. (2008). Individualized treatment for iron-deficiency anemia in adults. Amer. J. Med., 121 (11), 943-948.

Allison, M. C., Howatson, A. G., Torrance, C. J., Lee, F. D., Rusell, R. I. (1992). Gastrointestinal damage associated with the use of nonsteroidal antiinflammatory drugs. New Engl. J. Med., 327, 749-754.

Auerbach, M. (2020). Treatment of iron deficiency anemia in adults. https://www.uptodate.com/contents/treatment-of-iron-deficiency-anemia-in-adults?topicRef $=7150 \&$ source $=$ see_link (accessed 4 April 2020).

Bjarnason, I., Hayllar, J., Macherson, A. J., Russell, A. S. (1993). Side effects of non-steroidal anti-inflammatory drugs on the small and large intestine in humans. Gastroenterology, 104, 1832-1847.

Butt, Z., Lai, J. S., Rao, D., Heinemann, A. W., Bill, A., Cella, D. (2013). Measurement of fatigue in cancer, stroke, and HIV using the Functional Assessment of Chronic Illness Therapy - Fatigue (FACIT-F) scale. J. Psychosom. Res., 74 (1), 64-68.

Cella, D., Lai, J. S., Chang, C. H., Peterman, A., Slavin, M. (2002). Fatigue in cancer patients compared with fatigue in the general United States population. Cancer, 15, 528-538.

Contaldo, A., Losurdo, G., Albano, F., Iannone, A., Barone, M., Ierardi, E., Di Leo, A., Principi, M. (2019). The spectrum of small intestinal lesions in patients with unexplained iron deficiency anemia detected by video capsule. Endoscopy Med. (Kaunas), 55 (3), 59.

Cook, I. J., Pavli, P., Riley, J. W., Gouklston, K. J., Dent, O. F. (1986). Gastrointestinal investigation of iron deficiency anaemia. Brit. Med. J., 292, $1380 \mathrm{e} 2$.

De Benoist, B., McLean, E., Egli, I., Cogswell, M. (eds.). (2008). Worldwide Prevalence of Anaemia 1993-2005. WHO Global Database on Anaemia. 40 pp.

Derovs, A. (2012). The Clinical Significance of the Excavated Lesions in the Small Bowel. LAP LAMBERT Academic Publishing, 60 pp.

Feldman, M., Friedman, L., Brandt, L. (2010). Sleisenger \& Fordtran's Gastrointestinal and Liver Disease. 9th edn. Saunders Elsevier. 2480 pp.

Gerson, L. B., Fidler, J. L., Cave, D. R., Leighton, J. A. (2015). ACG Clinical guideline: Diagnosis and management of small bowel bleeding. Amer. J. Gastroenterol., 110, 1265-1287.

Ginsberg, G. G., Barkun, A. N., Bosco, J. J., Isenberg, G. A., Nguyen, C. C., Petersen, B. T., Silverman, W. B., Slivka, A., Taitelbaum, G. (2002). Wireless capsule endoscopy: August 2002. Gastrointest. Endosc., 56, 621-624.

Goddard, A. F., James, M. W., McIntyre, A. S., Scott, B. B.; British Society of Gastroenterology (2011). Guidelines for the management of iron deficiency anaemia. Gut, 60,1309-1316.

Goldstein, J., Eisen, G., Lewis, B., Gralnek, I. M., Zlotnick, S., Fort, J. G. (2005). Video capsule endoscopy to prospectively assess small bowel injury with celecoxib, naproxen plus omeprazole, and placebo. Clin. Gastroenterol. Hepatol., 3, 133-141.

Graham, D. Y., Opekun, A. R., Willingham, F. F., Qureshi, W. A. (2005). Visible small intestinal mucosal injury in chronic NSAID users. Clin. Gastroenterol. Hepatol., 3, 55-59.

Greenland. S., Senn, S. J., Rothman, K. J., Carlin, J. B., Poole, C., Goodman, S. N., Altman, D. G. (2016). Statistical tests, P values, confidence intervals, and power: A guide to misinterpretations. Eur. J. Epidemiol., 31, 337-350.

Guralnik, J. M., Eisenstaedt, R. S., Ferrucci, L., Klein, H. G., Woodman, R. C. (2004). Prevalence of anemia in persons 65 years and older in the United States: Evidence for a high rate of unexplained anaemia. Blood, 104, 2263-2268.

Hall, J. (2011). Guyton and Hall Textbook of Medical Physiology. 12th edn. Saunders Elsevier, 1120 pp.

Hacibekiroglu, T, Akinci, S, Basturk, A. R., Bakanay, S. M., Ulas, T., Guney, T., Dilek, I. (2013). A forgotten screening test for iron deficiency anemia: Oral iron absorption test. Clin. Ter., 164 (6), 495-497. 
Hardwick, R. H., Armstrong, C. P. (1997). Synchronous upper and lower gastrointestinal endoscopy is an effective method of investigating iron-deficiency anaemia. Brit. J. Surg., 84, 1725-1728.

Hoffman, R. (2013). Hematology: Basic Principles and Practice. 6th edn. Elsevier Saunders, Philadelphia, PA, pp. 439-441

James, M. W., Chen, C. M., Goddard, W. P., Scott, B. B., Goddard, A. F. (2005). Risk factors for gastrointestinal malignancy in patients with iron-deficiency anaemia. Eur. J. Gastroenterol. Hepatol., 17, 1197-1203.

Jensen, N. M., Brandsborg, M., Boesen, A. M., Yde, H., Dahlerup, J. F. (1998). Low-dose oral iron absorption test: Establishment of a reference interval. Scand. J. Clin. Lab. Invest., 58 (6), 511-519.

Kepczyk, T., Kadakia, S. C. (1995). Prospective evaluation of gastrointestinal tract in patients with iron-deficiency anemia. Dig. Dis. Sci., 40, 1283-1289.

Kumar, V., Abbas, A., Fausto, N., Aster, J. (2010). Robbins and Cotran Pathologic Basis of Disease. 8th edition. Saunders Elsevier, 1464 pp.

Ladas, S. D., Triantafyllou, K. Spada, C., Riccioniu, M. EW., Rey, J.-F., Niv, Y., Delvaux, M., Franchis, R. de, Costamagna, G., ESGE Clinical Guidelines Committee (2010). ESGE recommendations on VCE in investigation of small-bowel, esophageal, and colonic diseases. Endoscopy, 42, $220-227$.

Lewis, B. S., Eisen, G. M., Friedman, S. (2005). A pooled analysis to evaluate results of capsule endoscopy trials. Endoscopy, 37, 960-965

Maiden, L., Thjodleifsson, B., Theodors, A., Gonzalez, J., Bjarnason, I. (2005). A quantitative analysis of NSAID-induced small bowel pathology by capsule enteroscopy. Gastroenterology, 128, 1172-1178.

Miller, J. F. (2013). Iron deficiency anemia: A common and curable disease. Cold Spring Harb. Perspect Med., 3, 1-13.
Napierkowski, J. J., Maydonovitch, C. L., Belle, L. S., Brand, W. T., Jr., Holtzmuller, K. C. (2005). Wireless capsule endoscopy in a community gastroenterology practice. J. Clin. Gastroenterol., 39, 36-41.

Pokrotnieks, J. (2000). Gastrointestinālā endoskopija [Gastrointestinal Endoscopy]. Pilatus, Rīga, 31.-34. lpp.

Rey, J. F., Ladas, S., Alhassani, A., Kuznetsov, K., ESGE Guidelines Committee (2006). Video capsule endoscopy: Update to guidelines (May 2006). Endoscopy, 38, 1047-1053.

Rockey, D. C., Cello, J. P. (1993). Evaluation of the gastro-intestinal tract in patients with irondeficiency anemia. New Engl. J. Med., 329, 1691-1695.

Rondonotti, E., Villa, F., Mulder, C. J. J., Jacobs, M. A. J. M., de Franchis, R. (2007). Small bowel capsule endoscopy in 2007: Indications, risks and limitations. World J. Gastroenterol., 13 (46), 6140-6149.

Rosenzweig, P. H., Volpe, S. L. (1999). Iron, thermoregulation and metabolic rate. Crit. Rev. Food Sci. Nutr., 39, 131-148.

Sidhu, R., Sanders, D. S., Morris, A. J., McAlindon, M. E. (2008). Guidelines on small bowel enteroscopy and capsule endoscopy in adults. Gut, 57, $125-136$.

Yellen, S. B., Cella, D., Webster, K., Blendowski, C., Kaplan, E. (1997). Measuring fatigue and other anemia-related symptoms with the Functional Assessment of Cancer Therapy (FACT) measurement system. J. Pain Symptom Man., 13, 63-74.

Zuckerman, G., Benitez, J. (1992). A prospective study of bidirectional endoscopy (colonoscopy and upper endoscopy) in the evaluation of patients with occult gastrointestinal bleeding. Amer. J. Gastroenterol., 87, 62-66.

Received 20 February 2020

Accepted in the final form 18 March 2020

\section{DZELZS UZSŪKŠANĀS TRAUCĒJUMI PACIENTIEM AR ENTEROPĀTIJU: VIENA CENTRA STARPPOSMA ANALĪZE}

Saskan̄ā ar PVO datiem pasaulē ir aptuveni 2 miljardi cilvēku, kas cieš no anēmijas, galvenokārt dzelzs deficīta (DDA). Latents dzelzs deficīts bez anēmijas ir trīs reizes biežāks nekā DDA. Šādiem pacientiem jānovērtē tievās zarnas stāvoklis un jāizslēdz malabsorbcija. Pētījuma mērķis bija novērtēt iespējamo korelāciju starp dažādiem enteropātijas veidiem un dzelzs uzsūkšanās traucējumiem. Pētījums notika Latvijas Jūras Medicīnas centrā "Gastroklīnika" no 2014. līdz 2018. gadam. Dzelzs uzsūkšanās tests ar 50 mg orālo dzelzs glikonātu, kā arī FACIT anketēšana tika veikta visiem pacientiem. Visiem pacientiem, kas bija iekḷauti pētījumā, tika veikta arī video kapsulas endoskopijas (VKE) diagnostika. Kopumā pētījumā bija iekḷauti 48 pacienti, no tiem $41(85,4 \%)$ bija sievietes un 7 (14,6\%) — vīrieši. Enteropātija tika diagnosticēta 35 gadījumos: erozīva - 17, eritematoza - 12 un sastrēguma - 6 gadījumi. Uz VKE laiku pacientiem bija DDA. Kopumā 33 (68,7\%) pacientiem bija dzelzs uzsūkšanās traucējumi, no kuriem 8 nebija enteropātijas iezīmju, turpretī 25 pacientiem tika diagnosticēts kāds no enteropātijas paveidiem. DDA neuzrādīja statistiski nozīmīgu korelāciju ar enteropātiju. Tomēr iegūtie rezultāti liek domāt, ka pastāv potenciāli mainīgais lielums, ko varētu izskaidrot ar tievās zarnas malabsorbciju. Nepieciešami turpmāki pētījumi, lai izpētītu precīzu enteropātijas lomu DDA pacientiem. 